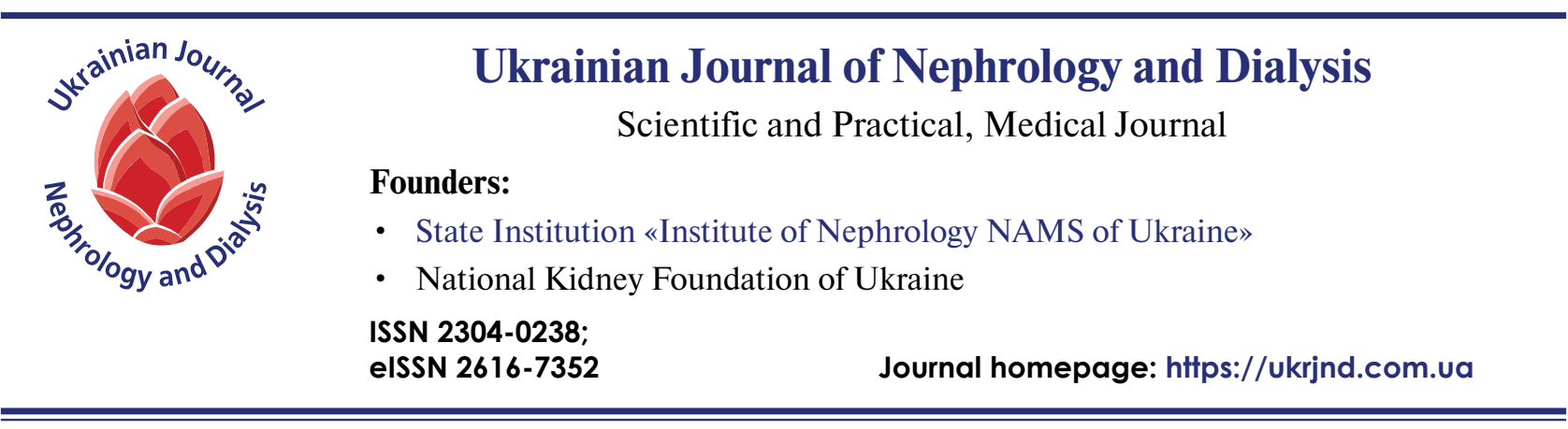

Research article

doi: $10.31450 /$ ukrjnd.2(70).2021.06
Farzana Danial ${ }^{1}$, Irfan Ullah Khattak ${ }^{2}$

\section{Psychological impact of COVID-19 pandemic on nurses: a qualitative study}

${ }^{1}$ Lady Reading School of Nursing, Peshawar, Pakistan

${ }^{2}$ Main Rashid Hussain Shaheed Memorial Hospital Pabbi, Khyber

Pakhtunkhwa, Pakistan

\section{Citation:}

Article history:

Received April 10, 2021

Received in revised form

May 18, 2021

Accepted May 18, 2021
Danial F, Khattak IU. Psychological impact of COVID-19 pandemic on nurses: a qualitative study. Ukr J Nephr Dial. 2021;2(70):48-55. doi: 10.31450/ukrjnd.2(70).2021.06
Abstract. Coronavirus disease is a serious infectious disease that spread very rapidly. Coronavirus not only impacts the general population but also a thread for health care providers. Besides, it psychologically impacts health care professionals especially nurses.

Objectives. To explore the psychological impact of the COVID-19 pandemic on nurses working in corona isolation units.

Methodology. A qualitative study was conducted using a phenomenological study design. Overall, data were collected from 15 nurses working in tertiary care hospitals of district Nowshera. The study was carried from 1st April 2020 to 20th May 2020. Permission was granted from the District Health Officer of District Nowshera. Keeping the spread of the coronavirus in view, data was collected through semistructured in-depth telephonic interviews. Electronic consent was also granted from all the concerned participants before data collection. Data were analyzed using Colaizzi's 7-step method.

Results. A total of three themes were generated from the data; Stress, social isolation, and Coping and Self-Care Styles. Nurses working in COVID-19 units experience stress due to constant duty change, fatigue, change in duty placement, and work overload. Also, they experience social isolation due to the fear of getting infected and the disease transmission to their family and other population. Coping and self-care styles such as exercise, physical activity, facing the reality and religious beliefs are important for the nurses to maintain their mental health.

Conclusions. The outbreak of COVID-19 psychologically impacts the nurses. Besides, the nurses experience stress and social isolation. The nurses also need coping and self-care styles to maintain their mental health. The role of the health department is very important to highlight this issue and provide proper assistance to the nurses.

Keywords: psychological impact, COVID-19, pandemic, nurses.

Conflict of interest statement. The authors declare no competing interest.

(C) Danial F., Khattak I.U., 2021. All rights reserved. 
(C) Danial F., Khattak I.U., 2021.

УДК 616.98:578.834]-036.21:614.253.52

\section{Фарзана Даніал ${ }^{1}$, Ірфан Улла Хаттак ${ }^{2}$ \\ Психологічний вплив пандемії COVID-19 на медсестер: Якісне дослідження}

${ }^{1}$ Школа медсестер, Пешавар, Пакистан

${ }^{2}$ Головний меморіальний госпіталь ім. Рашида Хуссейна Шахіда Паббі, Хайбер-Пахтунхва, Пакистан цівників.

Резюме. Коронавірусна хвороба впливає не тільки на загальну популяцію, але також і на медичних пра-

Меиою нашої роботи було вивчити психологічний вплив пандемії COVID-19 на медсестер, які працюють у відділеннях лікування коронавірусної хвороби.

Методи. Проведено якісне дослідження з використанням феноменологічного дизайну дослідження. Загалом, дані були зібрані від 15 медсестер з 1 квітня 2020 року по 20 травня 2020 року. Дозвіл було надано окружним медичним працівником Новшери. Зважаючи на поширення коронавірусної хвороби, дані збирали за допомогою напівструктурованих поглиблених телефонних інтерв'ю. Перед збором даних також була надана електронна згода від усіх зацікавлених учасників. Дані аналізували за допомогою 7-етапного методу Колайцці.

Результати. Всього з даних було створено три теми: стрес, соціальна ізоляція, стилі подолання та догляду за собою. Медсестри, які працюють у підрозділах COVID-19, відчувають стрес через постійну зміну чергування, втому, зміну місия роботи та перевантаження. Крім того, вони відчувають соціальну ізоляцію через страх заразитися та передачу хвороби своїи сім ї та іншому населенню. Визначено суттєві зміни у повсякденному житті медсестер, а саме можллвості займатись фізичними вправами, реалізація реальності та релігійні переконання, важливі для збереження свого психічного здоров'я.

Висновки. Епідемія COVID-19 психологічно впливає на медсестер. Крім того, медсестри відчувають стрес та соціальну ізоляцію. Медсестрам також потрібно максимальне збереження звичного стилю жсття, щоб зберегти своє психічне здоров я. Роль відділу охорони здоров'я дуже важллива для висвітлення цього питання та надання належної допомоги медсестрам.

Ключові слова: психологічний вплив, COVID-19, пандемія, медсестри.

Introduction. COVID-19 is initially identified in Wuhan, China, its new emerging infectious disease spread in china in December 2019 [1]. Initially, the symptoms of the disease were just like pneumonia and the disease was treated as pneumonia [2]. Wuhan, China was highlighted and all the focus was on the outbreak of the infectious respiratory disease with an unknown cause. Worldwide, health care authorities immediately pay attention to this killer disease after its confirmation as COVID-19 [3]. COVID-19 was declared a pandemic disease by the World Health Organization (WHO) on $11^{\text {th }}$ march 2020 due to its rapid spread around the globe [4]. Globally, a total of 37,704,153 confirmed cases are reported including 1,079,029 deaths [5]. Around 20\% of COVID-19 patients experience severe disease symptoms, need oxygenation therapy, and critical care. Only $5 \%$ of COVID-19 patients require Intensive Care Unit (ICU) admission and ventilation [6].

COVID-19 is an emerging disease and health care workers are fighting on the frontline to control this dis-

\author{
Farzana Danial \\ farzanakhokhar@yahoo.com
}

ease, helping and supporting the patients in rehabilitation $[7,8]$. Similarly, COVID-19 also has an impact on health care workers and leads to certain problems and challenges for this vital part of society. These problems include Personal Protective Equipments (PPEs), need for extra staff, ventilators, beds, and isolation units $[9,10]$.

Health care workers are the vital resources of any country, their health and safety are important not only for the care of patients but also for the control of any outbreak of infectious diseases. The health care providers experienced severe stress, understaffing, anxiety, stigmatization, comprehensive support, and mental health problems during care of the patients with severe acute respiratory syndrome (SARS) and the Middle East respiratory syndrome (MERS), the diseases similar to COVID-19 [11, 12].

According to the studies, nurses working on the front line and caring for patients with COVID-19 experience mental health problems, such as insomnia, stress, depression, and anxiety [13]. Similarly, another qualitative study also highlighted the psychological impact of COVID-19 on health care workers, the health care workers experience "being fully responsible for patients", "challenges of working" and "resilience amid challenges".

COVID-19, Pakistan is also on the list of COVID-19 affected countries. Health care providers es- 
pecially the nurses are fighting on the front line. The health of the nurses is very important because the nurses are the vital resource of the country and also the backbone of the health care system. There is not a single study published in Pakistan to highlight the psychological impact of COVID-19 on nurses taking care of coronavirus diseased patients. To support the nurses effectively in this crisis, it is necessary to gain their insights and to explore the psychological impact of COVID-19 on nurses working in corona units. The basic purpose of the study is to explore the psychological impact of COVID-19 on nurses taking care of COVID-19 patents in Khyber Pakhtunkhwa, Peshawar, Pakistan.

Methods. Research Design. A phenomenological method was used to qualitatively analyze the psychological impact of COVID-19 on nurses working in the COVID-19 unit taking care of patients infected with the coronavirus. The empirical phenomenological approach is one of the best approaches to explore the psychological impact of COVID-19 on participants. This scientific approach focuses and guarantees the authenticity of gathered experiences of participants according to scientific standards.

Study subjects. A total of 15 nurses taking care of COVID-19 positive patients were recruited using a convenient sampling method. All these nurses were recruited from tertiary care government hospitals (QaziHussain Ahmad and Districh Headquater Hospital) of district Nowshera, Khyber Pakhtunkhwa. The study was carried from $1^{\text {st }}$ April 2020 to $20^{\text {th }}$ May 2020. The nurses working in COVID-19 wards and taking care of conformed COVID-19 positive patients for at least two weeks and volunteers to participate in the study were included in the study.

Interview guide. The interview questions were designed using literature, taking opinions from experts, and reviewing previous studies. The following questions were asked to explore the psychological impact of COVID-19 on nurses talking care of COVID-19 patients. (1) What are the main psychological feelings of nursing care providers for COVID-19 patients? (2) What are your coping strategies? (3) What are your insights in the face of the epidemic? (4) What has changed in your life? (5) How do you cope with changes in your work and life? (6) What are your thoughts and feelings about this anti-epidemic task?
Data collection. Keeping in view the spread of COVID-19 and to improve the care of COVID-19, it was difficult to conduct a face-to-face interview because it was risky for both the participants and the research. Therefore, data were collected through semistructured in-depth telephonic interviews. Initially, the list and characteristics of the nurses working in COVID-19 units were gathered from the nursing offices of the hospitals. Afterward, the nurses were contacted through a telephonic call. The aims and objectives of the study were shared with the participants. Verbal and electronic (WhatsApp) consents were taken for the participants before the collection of the data. Proper times were fixed with the participants in their off-times with mutual agreement. The participants were assured that all the information will be kept confidential and the interview will be collected only by the first author. Approximately, it took 40 to $50 \mathrm{~min}-$ utes to complete the interview of one participant. All the interviews were recorded in a voice call recorder. The participants were allowed to discontinue the interview at any time. Data collection was stopped after data saturation.

Ethical Consideration. The study was approved from ethical review board of Nowshera Medical College. Permission was granted from the hospital directors of concerned hospitals. Approval was also granted from District Health Officer Nowshera.

Data analysis. After 24 hours of the interview, the recordings were transcribed. Colaizzi's phenomenological analysis method was used to analyze the data. Data were analyzed by two researchers independently by listing and reading more than two times. Codes and themes were extracted from the data.

Results. A total of 15 nurses were included in the study. Nine out of 15 nurses were female and more than half $(53 \%)$ nurses were from the age group 3140 years old. The majority $(73 \%)$ nurses were married and more than half $(53.33 \%)$ nurses were bachelor in nursing degree holders. The majority $(53.33 \%)$ of nursing staff were having experience between five to ten years while $26.66 \%$ of nursing were an experience of fewer than five years and only $13.33 \%$ of nurses experienced between 11 to 15 years. Results of participant's socio-demographic characteristics are displayed in Table 1.

Table 1

Demographic profile of the population, $(n=15)$

\begin{tabular}{|l|c|c|}
\hline \multicolumn{2}{|l|}{ Frequency } & Percent (\%) \\
\hline Gender & 6 & 40 \\
\hline Male & 9 & 60 \\
\hline Female & \multicolumn{2}{|}{} \\
\hline Age (years) & 3 & 20 \\
\hline$<$ than 30 years & 8 & 53.33 \\
\hline $31-40$ years & 4 & 26.66 \\
\hline$>$ than 40 years &
\end{tabular}


Continuation of Table 1

\begin{tabular}{|l|c|c|}
\hline \multicolumn{2}{|c|}{ Frequency } & Percent (\%) \\
\hline Marital Status & 4 & 26.66 \\
\hline Unmarried & 11 & 73.33 \\
\hline Married & 7 & 46.66 \\
\hline Education & 8 & 53.33 \\
\hline Diploma Nursing & 0 & 0 \\
\hline Bachelor in Nursing & \multicolumn{2}{|l|}{} \\
\hline Master in Nursing & 4 & 26.66 \\
\hline Experience & 8 & 53.33 \\
\hline$<$ than 5 years & 2 & 13.33 \\
\hline $5-10$ years & 1 & 6.66 \\
\hline $11-15$ years & 0 & 0 \\
\hline $16-20$ years & \multicolumn{2}{|l|}{} \\
\hline$>$ than 20 years & \multicolumn{2}{|l|}{} \\
\hline
\end{tabular}

Three themes were generated from the data analysis, these themes are Stress, social isolation, and Coping and Self-Care Styles.

Theme 1: Stress. Overall, all $(n=15)$ the participants express stress due to covid-19 spread. Work overload, fatigue, change of duty placement, and change in nurse's roster are certain factors that lead to stress among nursing staff. Participants express that duty in the corona unit; regular uses of personal protective equipment and prolonged duty lead to severe fatigue (Fig. 1).

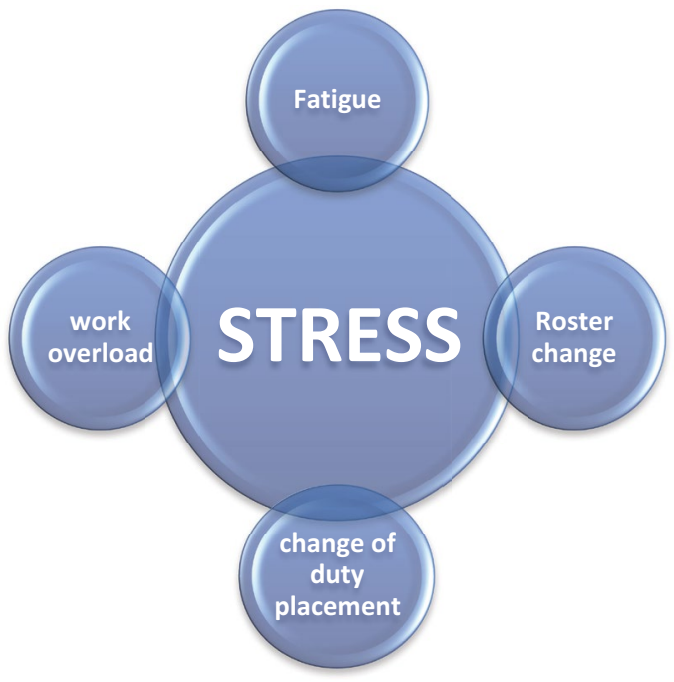

Fig. 1. Stress Among Nursing Working In Covid-19 Units.

"Normally we perform 8 hours shift but in corona unit, we perform 12 hours shift, I felt very restlessness after completion of my duty" $(n=8)$.

"I put on the covid-19 protective gowns and other protective equipment's before entering in the unit and put it off after duty shift. It makes me very tired because these kits are very uneasy" $(n=3)$.

"I cannot stretch my legs and my body in this tight protective kit, all the day standing and prolong duty make me very tired and I feel pain in my legs" $(n=15)$.
Nursing staff also express that the spread of covid-19 also increased the intensity of the workload. Also, the roster is changing to maintain staffing for the corona units. Changes in duty placement were also reported by the nursing staff.

"My duty was in the emergency unit, we were six nursing staff there to cover the unit, now my duty is in corona unit and I am alone in the unit. It hardly coves the unit work" $(n=2)$.

"I did my routine duty in children word. Due to corona spread our duty schedule has been changed and I am now performing my duty in corona ward. I am very exhausted due to this change" $(n=7)$.

"Our roster is changing, every second day we face some changes in the nursing roster to compensate for the shortage of nursing staff in the covid-19 unit. Every time, we are keeping our-self mentally prepare for the duty change" $(n=13)$.

Theme 2: Social Isolation. The second theme generated from the data is social isolation. This theme (social isolation) was generated from sub-themes such as self-protection, family protection, and fear of being a chain for the spread of covid-19 spread (Fig. 2).

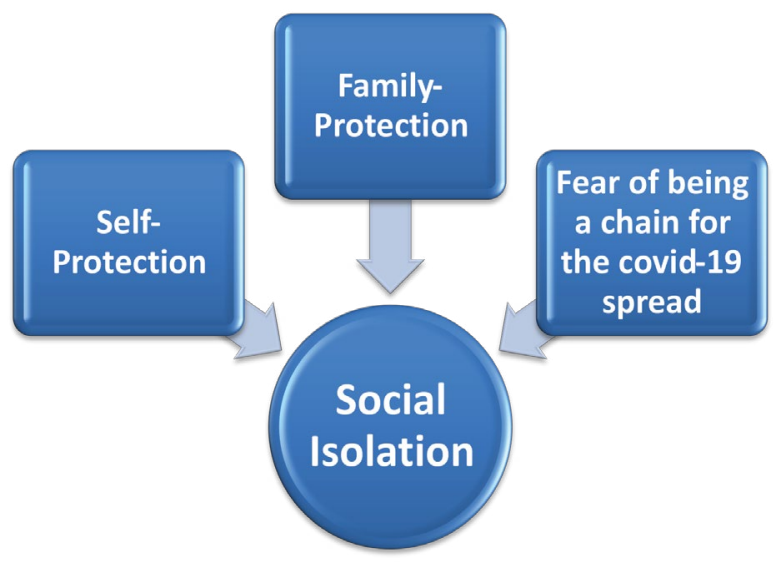

Fig. 2. Social Isolation among nurses working in Covid-19 unit. 
The nursing staff expresses that they feel socially isolated because they feel that they can be a carrier for the transmission of the covid-19 virus. Also, they can spread the virus to their family members the other people. Besides, social isolation can prevent their self, family members, and other population safe from covid- 19 .

"I treat every person in quarantine as covid-19 positive. I can't trust on whether the person to whom I meet is covid-19 positive or negative. I think every person is covid-19 positive" $(\mathrm{n}=13)$.

"After the spread of covid-19, I restrict myself from the other hospital staff. I restrict my interactions with any hospital staff even people outside the hospital. A little negligence can infect me with this virus" $(n=1)$.

"Even I use personal protective equipment's in hospital but still I am afraid of the transfer of the virus to my family members" $(\mathrm{n}=11)$.

"I didn't meet any member of my family when I of my duty and go back home due to the fear of virus transfer" $(n=4)$.
"I have a separate room in my home; I directly go to my room without touching anything and without meeting anybody in my home. I scrub my hands, take bath but still, I think I am unsafe and I will make the family members infected. This fear makes me usually isolate me from my family" $(n=9)$.

"Health care professionals especially the nurses are very prone to this infection. I make myself isolated from the community because there are limited personal protective equipment's in the hospitals and every day we hear positive cases of health care workers" $(n=7)$.

"I have two sons and one daughter. I separated them from myself. I can't express my feeling how I feel for them......" $(n=6)$.

Theme 3: Coping and Self-Care Styles. The third theme generated from the data was coping and self-care styles. The theme was generated from sub-themes such as psychological adjustment, life adjustment, facing the reality, and religious beliefs (Fig. 3).

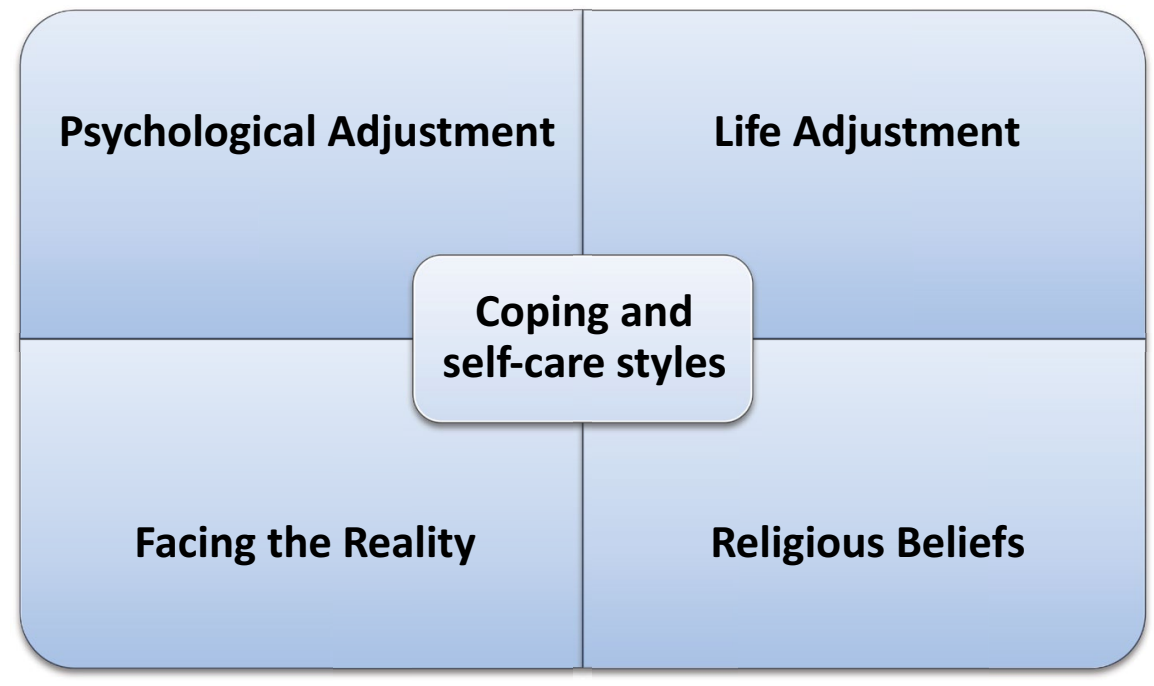

Fig. 3. Coping and self-care styles.

A majority $(n=11)$ of the participants express psychological adjustment in terms of coping with the corona outbreak.

"I keep my mind that this entire pandemic will become to end one-day InshAllah, Allah had fixed all the maters and no one can do anything" $(n=5)$.

"Corona is just like other infectious diseases and not a dangerous disease. We can protect ourselves from it if we keep ourselves protected by implementing infection control protocols. The mortality rate from the corona is very less" $(n=4)$.

"I think corona will take few days and when it gets summer corona will be finished, also Pakistani are immunized with different viruses and bacteria" $(n=10)$.

The participants also expressed that life adjustment is one of the best coping strategies to deal with the covid-19 outbreak and to adjust their life accordingly.
"To reduce my stress and tension of corona I went out in the fields and sit alone somewhere where I breathe fresh air and I relax" $(n=9)$.

"I have changed my nutrition, I used to take nutrition which increase my immunity and which increase my body resistance against covid-19. I think the best way to protect yourself from the corona is to improve your immunity through proper diet" $(n=4)$.

"We as a health professional are very prone to this disease. I think we should prepare ourselves for this outbreak. I used to exercise to release my tension and stress. I think indoor exercise is best remade for releasing the tension" $(\mathrm{n}=8)$.

Most $(n=9)$ of the participants revealed that corona is serious and real. They also stated that they have to face the reality of corona as professional nurses. Religious beliefs were also highlighted by the participants as a coping strategy to deal with the disease. 
"I think we should face the reality of corona spread and we should take it seriously and be preparing to fight against corona" $(n=9)$.

"No one is taking corona serious; corona is the reaction of our acts. I am mentally prepared to fight against this disease and prove my professionalism" $(n=14)$.

"We should return to Allah and cry in front of Allah, Allah should forgive us because this disaster can only be prevented by Allah" $(n=12)$.

"I feel relax and forget everything when I offer my prayer and I believe that no one can do anything except Allah" $(n=6)$.

"I recite the verses of Quran and offer my prayers five times a day. It makes me very relax and energetic. And am sure, InshAllah, we will defeat corona" $(n=1)$.

Discussion. The current study was designed to explore the psychological experiences of nurses caring for covid-19 positive patients using the phenomenological method. The findings of the study estimated 3 themes: stress, social isolation, and coping and self-care styles.

In this study, the nurses experience extreme stress due to work overload, fatigue, change of duty placement, and change in nurse's roster. Also, prolong duty in the corona unit and regular use of personal protective equipment lead to severe fatigue and eventually stress. The findings are consistent with the finds of the study conducted on Middle East Respiratory Syndrome and Ebola [14-16].

In the current study, the participants express their concern regarding their family members, a study conducted by Lee et al, revealed the same findings [17]. Also, several studies estimated consistent results and reported physical exhaustion, fear, anxiety, stress, and tension among nurses caring for patients with respiratory infective diseases $[\mathbf{1 4}, \mathbf{1 8}, \mathbf{1 9}]$.

The current study estimated that stress is the main problem of concern among nurses working in corona units. Therefore, Proper psychological assessment of nurses for stress is very necessary, and proper psychological interventions for the nurses are very important during this pandemic disease. It is very important to conduct a stress assessment of each nurse caring for corona infected patients. The nurses should be facilitated in terms of relief, rest, scheduled duty, and duty with the time frame. Similarly, the nurses working in such infective units should be treated flexibly and interventions should be applied to overcome their stress and their mental health should be the priority $[14,17,20,21]$.

The current study also explores social isolation among nurses working in corona units. They express the main reason for social isolation is self-protection, family protection, and fear of being a chain for the spread of covid-19 spread. Another study provides consistent results in accordance with the current study and estimated that the nurses were concerned about transferring the infection to their family members [17]. In the same context, a study conducted by Anliu et al, provided consistent results and estimated that $25 \%$ of nurses working in corona units experience psychological distress among with the majority $(83 \%)$ are concern about the disease transfer to their family and others [22]. In the same way, another study also revealed the same finding and stated that the basic factor for nurse's stress is the fear of transferring the infection to their-self, family members, and other populations [23]. A study conducted by Pratik et al, estimated consistent findings and reported that nurses feel fear to be infected with the coronavirus and may spread the virus to other healthy populations [24].

The effect of COVID-19 on health care professionals has been highlighted in various studies and it is estimated that social isolation and loneliness is one of the most affected health care outcomes among nurses which impacts the nurses mentally and physically. There is a need for proper assessment of nurses caring for COVID-19 patients and there should be proper interventions for the nurses to break the chain of social isolation. Social isolation may lead to severe mental health complications. Interventions such as socialconnection, community-based networks, mobilizing the resources from family members, and engaging the health care system to begin the process of developing methods to identify social isolation and loneliness in health care settings are very important for healthy nurses $[25,26]$.

Coping and self-care styles were also reported among the nurses caring for COVID-19 patients in the current study. The study conducted by Niuniu et al, provides consistent findings in accordance with the current study and revealed that nurses adopt psychological adjustment and life adjustment dealing with COVID-19 patients [21]. Findings such as psychological adjustment and life adjustment of nurses caring for patients with severe respiratory infectious diseases were consistently reported in other studies [27-29].

It is reported that coping style, social support, cognitive evaluation play an important role in breaking the chain of stress [29]. fThe study estimated that nurses especially females experience severe stress and anxiety working in COVID-19 units, several coping strategies such as focus group coping and emotional focus coping are very effective coping strategies for the nurses caring for COVID-19 patients [30]. Physical activity and excise were estimated the best therapy for the nurses to cope with stress and tension [31]. Therefore, interventions regarding coping and lifestyle changes are necessary for the nurses to deal with the stress and tension due to COVID-19 and the health care organizations take it seriously to provide a coping pathway for the nurses for their good health.

Limitations. This was a qualitative study; the sample size we selected was 15 nurses. This limited sample size was due to the characteristics of qualitative research. Only nurses were included, it would be better to explore the psychological effect of COVID-19 on other health care professionals as well. Due to COVID-19 spread and keeping the safety measures of in- 
fection preventions we were unable to conduct focus group interviews and face to face interviews. In addition, it was a short time study in the initial spread of disease.

Conclusion. In this study, the psychological impact of COVID-19 on nurses working in COVID-19 units was explored. It is estimated that the nurses working on the front line in COVID-19 units experience

\section{References:}

1. Hui DS, I Azhar E, Madani TA, et al. The continuing 2019-nCoV epidemic threat of novel coronaviruses to global health - The latest 2019 novel coronavirus outbreak in Wuhan, China. Int J Infect Dis. 2020;91:264-266. doi: 10.1016/j.ijid.2020.01.009.

2. WHO | Pneumonia of unknown cause - China. Available from: https://www.who.int/csr/don/05january-2020-pneumonia-of-unkown-cause-china/en/. [accessed 14 Oct 2020].

3. Chang D, Xu H, Rebaza A, Sharma L, Dela Cruz $C S$. Protecting health-care workers from subclinical coronavirus infection. Lancet Respir Med. 2020;8:e13. doi: 10.1016/S2213-2600(20) 30066-7.

4. WHO/Europe | Coronavirus disease (COVID-19) outbreak - WHO announces COVID-19 healthtopics/health-emergencies/coronavirus-covid-19/ news/news/2020/3/who-announces-covid19-outbreak-a-pandemic. Available from: https:// www.euro.who.int/en/ [accessed 14 Oct 2020].

5. WHO Coronavirus Disease (COVID-19) Dashboard | WHO Coronavirus Disease (COVID-19) Dashboard. Available from: https:// covid19.who.int/. [accessed 14 Oct 2020].

6. Wu Z., M McGoogan J. Characteristics of and important lessons from the coronavirus disease 2019 (COVID-19) outbreak in China. JAMA - J Am Med Assoc 2019;2639-2648. doi: 10.1001/jama.2020.2648.

7. Sarti TD, Lazarini WS, Fontenelle LF, Almeida $A P S C$. What is the role of Primary Health Care in the COVID-19 pandemic? Epidemiol e Serv saude Rev do Sist Unico Saude do Bras. 2020; 29:e2020166. doi: 10.5123/s1679-49742020000200024.

8. Melvin SC, Wiggins C, Burse N, Thompson E, Monger M. The role of public health in COVID-19 emergency response efforts from a rural health perspective. Prev Chronic Dis. 2020; 17:1-6. doi: 10.5888/PCD17.200256.

9. Lippi G, Sanchis-Gomar F, Henry BM. Coronavirus disease 2019 (COVID-19): the portrait of a perfect storm. Ann Transl Med. 2020; 8, 7:497-497. doi: 10.21037/atm.2020.03.157.

10. Puradollah M, Ghasempour M. Necessity of attention to mental health of the front line nurses against COVID-19: A forgotten requirement. Int J Community Based Nurs Midwifery. 2020;8 (3):280_ 281. doi: 10.30476/IJCBNM.2020.85889.1301. stress due to constantly duty change, fatigue, change in duty placement, and work overload. Also, they experience social isolation due to the fear of getting infected and the disease transmission to their family and other population. Coping and self-care styles such as exercise, physical activity, facing the reality and religious beliefs are important for the nurses to maintain their mental health.

11. Maunder R, Hunter J, Vincent L, Bennett J, Peladeau $N$, Leszcz M, Sadavoy J, Verhaeghe LM, Steinberg $R$, Mazzulli $T$. The immediate psychological and occupational impact of the 2003 SARS outbreak in a teaching hospital. Cmaj. 2003;168(10):12451251. Available from: https://pubmed.ncbi.nlm. nih.gov/12743065/.

12. Lai AL, Millet JK, Daniel S, Freed JH, Whittaker $G R$. Psychological impact of 2015 MERS. Lancet. 2020;395:1315.

13. Liu S, Yang L, Zhang C, Xiang YT, Liu Z, Hu S, Zhang $B$. Online mental health services in China during the COVID-19 outbreak. The Lancet Psychiatry. 2020; 7:e17-e18. doi: 10.1016/S22150366(20)30077-8.

14. Kang HS, Son YD, Chae SM, Corte C. Working experiences of nurses during the Middle East respiratory syndrome outbreak. Int J Nurs Pract. 2018; 24:1-8. doi: 10.1111/ijn.12664.

15. $R n Y K$. Nurses' experiences of care for patients with Middle East respiratory syndrome-coronavirus in South Korea. Am J Infect Control. 2018; 46:781-7. doi: 10.1016/j.ajic.2018.01.012.

16. Smith $M W$, Smith PW, Kratochvil CJ, Schwedhelm $S$. The Psychosocial Challenges of Caring for Patients with Ebola Virus Disease. Heal Secur. 2017;15:104-109. doi: 10.1089/hs.2016.0068.

17. Lee SH, Juang YY, Su YJ, Lee HL, Lin YH, Chao CC. Facing SARS: Psychological impacts on SARS team nurses and psychiatric services in a Taiwan general hospital. Gen Hosp Psychiatry. 2005; 27:352-358. doi: 10.1016/j.genhosppsych.2005.04.007.

18. Khalid I, Khalid TJ, Qabajah MR, Barnard AG, Qushmaq IA. Healthcare workers emotions, perceived stressors and coping strategies during a MERS-CoV outbreak. Clin Med Res. 2016 ; 14:714. doi: 10.3121/cmr.2016.1303.

19. O'Boyle C, Robertson C, Secor-Turner M. Nurses' beliefs about public health emergencies: Fear of abandonment. Am J Infect Control. 2006;34:351357. doi: 10.1016/j.ajic.2006.01.012.

20. Li W, Yang Y, Liu ZH, Zhao YJ, Zhang Q, Zhang L, Cheung T, Xiang YT. Progression of mental health services during the COVID-19 outbreak in China. Int J Biol Sci.2020; 16:1732-1738. doi: 10.7150/ ijbs. 45120 . 
21. Sun N, Wei L, Shi S, et al. A qualitative study on the psychological experience of caregivers of COVID-19 patients. Am J Infect Control. 2020; 48:592-298. doi: 10.1016/j.ajic.2020.03.018.

22. Nie A, Su X, Zhang S, Guan W, Li J. Psychological impact of COVID-19 outbreak on frontline nurses: A cross-sectional survey study. J Clin Nurs. 2020; 29:4217-4226. doi: 10.1111/jocn.15454.

23. Health I, Cabarkapa S, Nadjidai SE, Murgier J, $\mathrm{Ng} \mathrm{CH}$. Since January 2020 Elsevier has created a COVID-19 resource centre with free information in English and Mandarin on the novel coronavirus COVID- 19. The COVID-19 resource centre is hosted on Elsevier Connect, the company's public news and information. Brain, Behav Immun Heal.2020; 8:234-243.

24. Khanal P, Devkota N, Dahal M, Paudel K, Joshi D. Mental health impacts among health workers during COVID-19 in a low resource setting: A crosssectional survey from Nepal. Global Health.2020; 16:1-12. doi: 10.1186/s12992-020-00621-z.

25. Hendy A, Abozeid A, Sallam G, Abboud Abdel Fattah $H$, Ahmed Abdelkader Reshia F. Predictive factors affecting stress among nurses providing care at COVID-19 isolation hospitals at Egypt. Nurs Open.2020; 8,1:498-505 doi: 10.1002/nop2.652.

26. $W u B$. Social isolation and loneliness among older adults in the context of COVID-19: a global challenge. Glob Heal Res Policy.2020; 5:154-156. doi: 10.1186/s41256-020-00154-3.
27. Main A, Zhou Q, Ma Y, Luecken LJ, Liu X. Relations of sars-related stressors and coping to chinese college students' psychological adjustment during the 2003 beijing sars epidemic. J Couns Psychol.2011;58:410-423. doi: 10.1037/a0023632.

28. Skapinakis P, Bellos $S$, Oikonomou A, Dimitriadis $G$, Gkikas $P$, Perdikari E, Mavreas V. Depression and its relationship with coping strategies and illness perceptions during the Covid-19 lockdown in Greece: A cross-sectional survey of the population. Depress Res Treat. 2020. doi: 10.1155/2020/3158954.

29. Mak WWS, Law RW, Woo J, Cheung FM, Lee D. Social support and psychological adjustment to SARS: The mediating role of self-care selfefficacy. Psychol Heal.2009; 24:161-174. doi: 10.1080/08870440701447649.

30. Huang L, Lei W, Xu F, Liu H, Yu L. Emotional responses and coping strategies in nurses and nursing students during Covid-19 outbreak: A comparative study. PLoS One.2020; 15: e0237303. doi: 10.1371/ journal.pone.0237303.

31. Savic M, Ogeil RP, Sechtig MJ, Lee-Tobin P, Ferguson N, Lubman DI. How do nurses cope with shift work? A qualitative analysis of open-ended responses from a survey of nurses. Int $\mathbf{J}$ Environ Res Public Health.2019; 16:3821. doi: 10.3390/ ijerph16203821. 